\title{
Parameters of interaction of a hydro impulse device with a coalseam during its loosening
}

\author{
Dmytro Vasyliev ${ }^{1, *}$ \\ ${ }^{1}$ Institute of Geotechnical Mechanics named by N. Poljakov of National Academy of Sciences of \\ Ukraine, 49005, Dnipro, Simferopolska Str., 2a, Ukraine
}

\begin{abstract}
In the Institute of Geotechnical Mechanics of the National Academy of Sciences of Ukraine (IGTM NAS of Ukraine), in order to improve the efficiency of hydro loosening in order to prevent sudden emissions of coal and gas, a method and device for impulse hydro loosening of coal seams are developed at the patent level. The device is based on the principle of periodic cavitation and is equipped with means for monitoring and controlling pressure in the filter cavity of the well backwater pressure. Laboratory studies have established that the device provides maximum values of the range of pressure fluctuations at low values of the backwater. The backwater is formed by the hydraulic pressure necessary for the development of shear cracks. A method for calculating this pressure in order to compare its values with rational backwater values has been developed. In addition, the device has a backwater pressure control mechanism for bringing the device to a rational mode of its operation.
\end{abstract}

\section{Introduction}

For more than a hundred years in the coal industry there has been an acute problem of preventing terrible phenomena - sudden coal (rock) and gas emissions. To prevent these phenomena, about a dozen local methods have been developed. The most common method is the method of hydro loosening [1].

Years of experience in the application of the method shows that the injection of fluid in a static mode can provoke gas dynamic phenomena [1]. Therefore, in hazardous areas, excavations are carried out using drilling and blasting operations in a shaking blasting mode. As a result, the rate of excavation is reduced by more than two times, and the costs increase significantly.

It is customary to divide the process of introducing fluid into the seam into four modes: filtration, hydro dissection, hydro fracturing, hydro erosion. Filtration is such a mode in which the rate of injection does not exceed the natural injectivity of the seam. In this case, the formation is not mechanically disturbed. Filtration mode does not have a significant effect on the bearing capacity of the seam, as it does not lead to the development of cracks.

${ }^{*}$ Corresponding author: vleonid1937@gmail.com 
Hydro fracturing can lead to a sharp hydro-pressing of the bottomhole part of the excavation. Hydro fracturing sometimes causes a sudden release of coal and gas. The most acceptable for reducing the bearing capacity of the impact-hazadeous formation is the formation of cracks in shear mode. The formation of cracks provides unloading of the nearwellbore part of the reservoir from rock pressure and the release of methane from it in the hydro-erosion mode, when the rate of fluid injection does not substantially exceed the natural injectivity of the formation in the filtration mode. The question of the transition of cracks from the state of the development of shear cracks to the state of hydro fracturing is relevant in case of hydro loosening. Therefore, in case of hydro loosening, it is important to limit the flow rate of the liquid in order to eliminate the dangerous hydro-pressing. To do this, it is necessary to justify the maximum performance of the pumping unit. We use the authors' developments of the book [2]. The authors present interesting generalized data of the crack width depending on the flow rate of the fluid supplied from it.

\section{Methods}

The maximum width of the formed crack $\omega_{c r}$ was determined by the following formulas and empirical dependencies.

Geerstsman and Clerk dependence

$$
\omega_{c r}=\left(\frac{336}{\pi}\right)^{\frac{1}{4}} \cdot\left(\frac{\mu_{l} \cdot Q_{l} \cdot l_{c r}^{2}}{m}\right)^{\frac{1}{4}}
$$

where $Q_{l},-$ flow rate, $\mathrm{m}^{3} / \mathrm{s}$ and $\mu_{l},-$ viscosity of the injected fluid, $\mathrm{Pa} \cdot \mathrm{s} ; l_{c r}$ - half-length crack, $\mathrm{m} ; m$ - seam capacity, $\mathrm{m}$;

Yu.P. Zheltov dependence

$$
\omega_{c r}=\frac{4(1-2 v) \cdot(1+v) \cdot\left(P_{c}-P_{h o r}\right)}{3 E} l_{c r}^{0.5},
$$

where $P_{c}$ - well pressure, $\mathrm{Pa} ; P_{\text {hor }}-$ lateral rock pressure, $\mathrm{Pa} ; E$ - elastic modulus (Young's) $\left(2 \cdot 10^{10} \mathrm{~Pa}\right) ; \mathrm{v}-$ Poisson's ratio $(0.27)$;

Perkins-Kern dependence

$$
\omega_{c r}=3.57 \cdot\left(\frac{\mu_{l} \cdot Q_{l} \cdot l_{c r}}{E^{\prime}}\right)^{\frac{1}{4}},
$$

where $E^{\prime}$ - is the modulus of plane strain $E^{\prime}=E /\left(1-v^{2}\right)$;

method «PKN»

$$
\omega_{c r}=3.27 \cdot\left(\frac{\mu_{l} \cdot Q_{l} \cdot l_{c r}}{E^{\prime}}\right)^{\frac{1}{4}} .
$$

Identification of the Zheltov and Perkins-Kern model with a full-scale object shows the possibility of using these dependencies in solving practical problems.

So, the Figure 1 shows that a crack with a width of $0.02 \mathrm{~m}$ occurs at a flow rate of $0.01 \mathrm{~m}^{3} / \mathrm{s}$ [2]. If, when hydro dissection is taken, the crack width is $0.002 \mathrm{~m}$, then the permissible flow rate will be $0.001 \mathrm{~m}^{3} / \mathrm{s}$. Then the permissible maximum capacity of the 
pump unit will be $0.001 \mathrm{~m}^{3} / \mathrm{s}$. This value corresponds to the productivity of the serial UNI01 pumping unit at $9.2 \cdot 10^{-4} \mathrm{~m}^{3} / \mathrm{s}$.

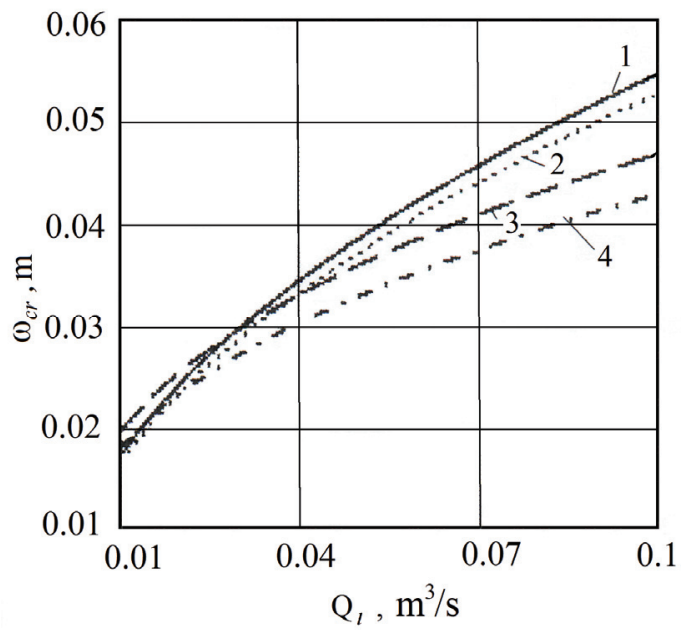

Fig. 1. Change the crack width of the hydro fracturing depending on the flow rate: 1 - 4 - calculated by dependencies (1) - (4).

Now we will focus on the impulsive method of hydro loosening [3-10]. Previously, several methods have been developed to prevent sudden coal and gas emissions, based on the effect of vibration. It is assumed that the increase in the effect of unloading of seams by dynamic methods during hydro loosening occurs due to a decrease in the values of coal frictional parameters. In case vibration, the softening of coal occurs. There is a destruction not only from the axial load, but also due to the reduction of lateral forces. To ensure vibration, the method and device of the hydro impulse effect on coal seams were developed at the level of patents of Ukraine [11] (in this digest, a description of the device is set out in the article «Control mode unit of a cavitation generator for impulse hydro-loosening of coal beds»). The device is equipped with means for monitoring and controlling pressure in the filtering cavity — backpressure. Reducing the discharge pressure to a certain value by draining a part of the fluid from the well through the channel of the reverse flow of fluid brings the device to a rational mode of its operation while maintaining high values of impulse hydraulic pressure.

The idea of the device is to use the phenomenon of the formation of elastic cavitation oscillations in the fluid flow when it is injected into a coal seam through a channel like a Venturi tube to create a vibratory effect in the formation and to develop inclined cracks. The most complete results of studies of cavitation fluid flow of domestic and foreign authors are presented in [12]. These studies show that in the case of cavitation regimes of fluid flow, as a result of the separation and collapse of cavitation cavities in contact with the wall of local hydraulic resistance, local increased impulse pressures occur.

The phenomenon of the effect of vibration on a porous medium has long been known. To assess the level of seam unloading, we will use earlier studies in the field of rock softening under the vibration. At the end of the last century in IGTM NAS of Ukraine, Institute of Mining (IGD) named by A.A. Skochinsky and other institutions conducted studies on the vibration and cyclic effects on coal and rocks. The fact of strength reduction under these effects is established. In connection with the problem of rock bursts and sudden discharges, IGTM NAS of Ukraine, IGD named by A.A. Skochinsky and other institutions the scientists E.V. Lodus, S.L. Romanovsky (St. Petersburg) investigated the properties of impact-hazardous coal. Also found a drop in the strength of coal with increasing strain rate. 
A particularly sharp drop in strength, twice, is observed at a strain rate of $\dot{\varepsilon}=10 \mathrm{~s}^{-1}$. Then the coal deformation rate is represented as

$$
\dot{\varepsilon}=\frac{d \varepsilon}{d t}=\frac{\Delta P z}{E}=10 \mathrm{~s}^{-1}
$$

where $\varepsilon$ - longitudinal deformation; $t$ - time, s; $\Delta P$ - sweep pressure of fluid, $\mathrm{Pa} ; z-$ impulse frequency, $\mathrm{Hz} ; E=5 \cdot 10^{8} \mathrm{~Pa}-$ coal elastic modulus.

On the basis of the stated results, the substantiation of the minimum necessary parameters of the cavitation generator using the formula

$$
z=\frac{10 E}{\Delta P} \text {. }
$$

\section{Results and discussion}

It is more important for us to know the value of the elasticity modulus of the coal seam perpendicular to the bedding, since in this direction the dynamic impact drives the cracks inclined to the bedding. Figure 2 shows the theoretical dependences of the rational frequency of the pressure impulses on their value according to expression (6). The experimental operating points of the device for impulse injection of fluid into the coal seam when the inlet pressure in the well varies from 3.1 to $14.4 \mathrm{MPa}$ and the discharge pressure of $22 \mathrm{MPa}$ are also presented here. As can be seen from the presented data, the parameters of the dynamic loading of the coal seam during impulsive hydro loosening completely correspond to the conditions of the theoretical dependencies of the rational impulse repetition rate on the magnitude of the pressure impulse. As a rule, working experimental points of the device are above theoretical dependencies.

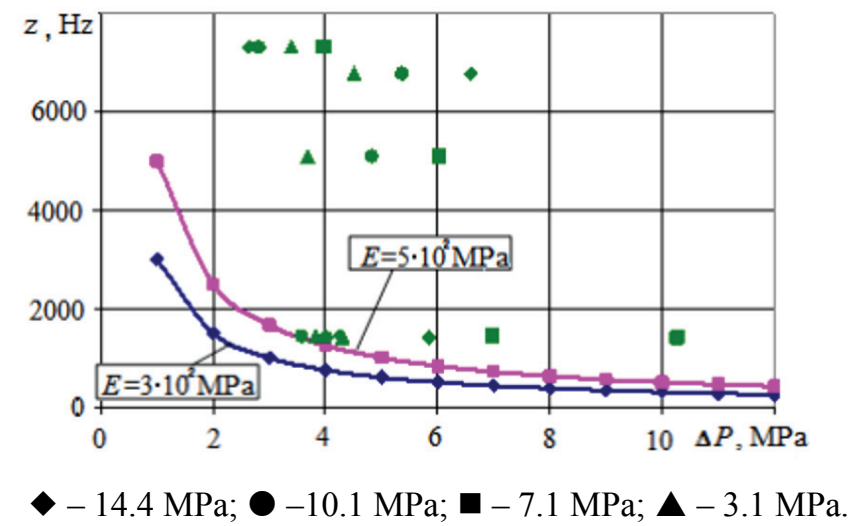

Fig. 2. The theoretical dependencies of the rational impulse repetition rate on their magnitude at values of the elastic modulus of coal $E=5 \cdot 10^{2} \mathrm{MPa}$ and $E=3 \cdot 10^{2} \mathrm{MPa}$ and experimental points of the device of impulse impact on the coal seam under a discharge pressure of $22 \mathrm{MPa}$.

To find out the rational operational parameters of the impulse hydro loosening device according to the pressure criteria of the backwater, we present the results of experimental studies of amplitude-frequency characteristics (AFC) of the elastic oscillator (Fig. 3) [13]. The Figure 3 shows that the well pressure values of the $P_{\mathrm{c}}$ (equal to backwater pressure $P_{\mathrm{b}}$ ) should be in the range of 0.5-4.0 $\mathrm{MPa}$. With these values, the device provides the highest values of the impulse width of the hydraulic pressure. To determine the value of pressure $P_{c}$, an appropriate method of its calculation is required. 


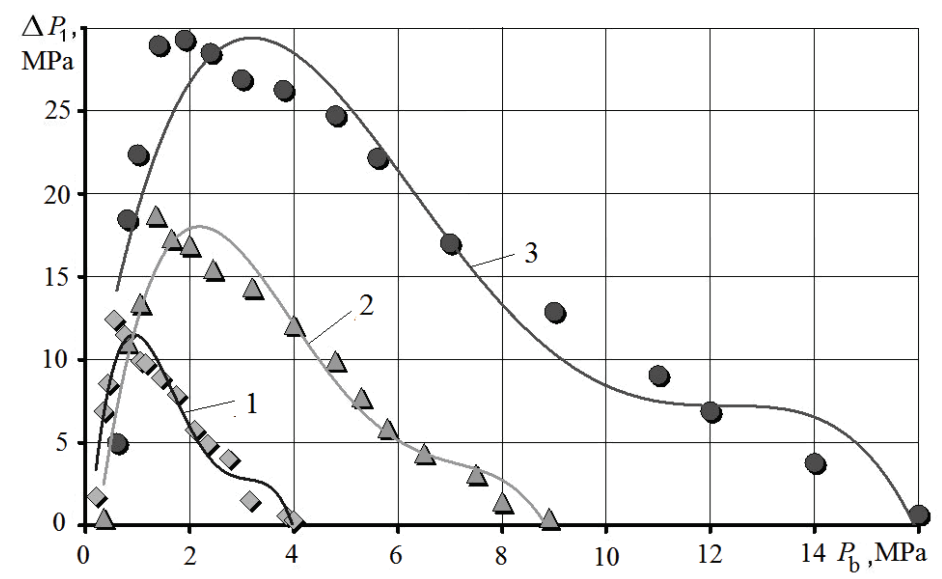

Fig. 3. Experimental dependences of the amplitude of oscillations $\Delta P_{1}$ on the backwater pressure $P_{\mathrm{b}}$ at different pumping modes $P_{\mathrm{p}}: 1-P_{\mathrm{p}}=15 \mathrm{MPa} ; 2-P_{\mathrm{p}}=25 \mathrm{MPa} ; 3-P_{\mathrm{p}}=35 \mathrm{MPa}$.

We use the well-known Coulomb's formula during the developing a method [14]

$$
k_{n}=\left|\tau_{\alpha}\right|-\mu \sigma_{\alpha}
$$

where $k_{n}$ - coal shear strength, $\mathrm{Pa} ; \tau_{\alpha}$ - active shear stresses, $\mathrm{Pa} ; \mu$ - internal friction coefficient; $\sigma_{\alpha}-$ normal stress on the trajectory of maximum effective tangential stresses (TMETS), Pa.

To solve the problem, we introduce the well pressure of the $P_{\mathrm{c}}$ fluid into the component of expression $\sigma_{\alpha}$ (7) and present the expression (7) in the form [14]

$$
\begin{aligned}
& k_{n}=-\frac{\sigma_{x}-\sigma_{y}}{2} \sin 2 \alpha+f \sigma_{y}\left(1-\frac{2 y}{h}\right) \cos 2 \alpha- \\
& -\mu\left(\frac{\sigma_{x}+\sigma_{y}}{2}-\frac{\sigma_{x}-\sigma_{y}}{2} \cos 2 \alpha-f \sigma_{y}\left(1-\frac{2 y}{h}\right) \sin 2 \alpha-P_{c}\right),
\end{aligned}
$$

where $\sigma_{y}$ and $\sigma_{x}$ vertical (rock pressure) and horizontal backwater stresses, Pa; $\alpha-$ tilt angle TMETS relatively horizontal, rad; $f$ - contact friction coefficient; $h$ - seam width, $\mathrm{m}$.

Horizontal stress backwater is determined by the formula [14]

$$
\sigma_{x}=\frac{2\left(k_{n}+\mu \sigma_{y}\right)}{\cos \rho}\left(\sin \rho-\sqrt{1-b^{2}}\right)+\sigma_{y},
$$

where $\rho=\operatorname{arctg} \mu-$ angle of internal friction of coal, rad;

$$
b=\frac{f \sigma_{y}}{k_{n}+\mu \sigma_{y}} ;
$$

Crack angle $\alpha$ calculated by the formula [14]

$$
\alpha=\frac{7 \pi}{4}-\frac{\rho}{2}-\beta,
$$

where 


$$
\beta=-\frac{1}{2} \operatorname{arctg} \frac{b \cos \rho}{\sin \rho-\sqrt{1-b^{2}}} .
$$

Then from expression (8) we have

$$
\begin{aligned}
& P_{c}=\frac{k_{n}}{\mu}+\frac{1}{\mu}\left(\frac{\sigma_{x}-\sigma_{y}}{2} \sin 2 \alpha-f \sigma_{y}\left(1-\frac{2 y}{h}\right) \cos 2 \alpha\right)+ \\
& +\left(\frac{\sigma_{y}+\sigma_{x}}{2}+\frac{\sigma_{x}-\sigma_{y}}{2} \cos 2 \alpha-f \sigma_{y}\left(1-\frac{2 y}{h}\right) \sin 2 \alpha\right)
\end{aligned} .
$$

Figure 4 shows the values of this pressure as a function of indicators of the properties of coal for a well sealing depth of $5.0 \mathrm{~m}$ along the ordinates of the seam thickness. As can be seen, the pressure values at the outfall of the filtration cavity of the well in ordinate $y$ (in different sections of the reservoir) are in the range from 0 to $3.0 \mathrm{MPa}$. Now compare these values with the backwater pressure at the outlet of the fluid from the generator (Fig. 3).

From comparing the values of the sub-pressure according to Figure 4 it can be seen that the pressure values at the outfall of the filtration cavity of the well and the pressure of the liquid overhead at the outlet of the cavitation generator are equivalent. This indicates the provision of an effective mode of the cavitation device during its interaction with the coal seam. In addition, the device has a backwater pressure control mechanism. The mechanism brings the device to a rational mode of its operation at high values of hydraulic pressure necessary for the development of a crack.

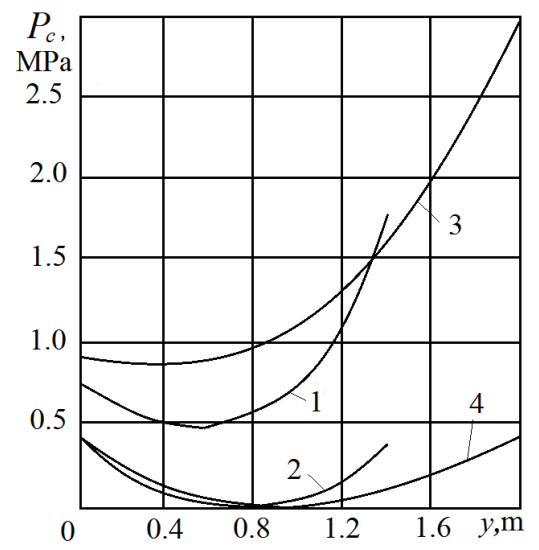

Fig. 4. Dependencies of fluid pressure required for the development of a crack in the mouth of the filtration cavity of a well, from ordinates for seams with a capacity of $1.4 \mathrm{~m}: 1-$ for $\rho=0.52 \mathrm{rad} ; 2-$ for $\rho=0.78 \mathrm{rad}$ and a capacity of $2.0 \mathrm{~m} ; 3-$ for $\rho=0.52 \mathrm{rad} ; 4-$ for $\rho=0.78 \mathrm{rad}$.

\section{Conclusions}

The IGTM of the NAS of Ukraine has developed a method and device for impulse hydro loosening of coal seams at the level of the patents of Ukraine. The device is equipped with means for monitoring and controlling pressure in the filter cavity - backwater pressure.

A hyperbolic pattern between the minimum necessary frequency and the range of pressure impulses during impulse hydro loosening has been established.

Laboratory studies have established that the device provides maximum values of the range of fluctuations of fluid pressure at low values of the backwater. The backwater 
pressure is generated by the hydraulic pressure necessary for the development of shear cracks. To compare the values of this pressure with the required values of the backwater on the device, a method for their calculation has been developed. In addition, a discharge pressure control mechanism is provided in the device. Reducing the discharge pressure to a certain value by draining a part of the fluid from the well through the backflow channel of the fluid brings the device to a rational mode of its operation while maintaining high values of impulse hydro pressure.

\section{References}

1. Yashchenko, I.A., Nikiforov, A.V., Mkhatvari, T.Ya., Ryzhov M.F. (2012). Ob otrabotke ugolnykh plastov Donbassa, sklonnykh k gazodinamicheskim yavleniyam. Ugol Ukrainy, 9, 15-20

2. Sadovenko, I.A. Rudakov, D.V., Inkin A.V. (2016). Geotekhnologiya osvoyeniya yemkostnykh i gazogidrotermalnykh resursov Donbassa. VNZ «NGU Ukrainy», Dnepropetrovsk

3. Vasyliev, L.M., Demchenko, V.C., Rodin A.V. (2001). Impulsnaya nasosnaya ustanovka. Geo-technical mechanics. Dnepropetrovsk, 29, 3-8

4. Vasyliev, L.M., Zhulai Yu.A., Trokhimets, M.Ya, Moyseenko P.Yu. (2005). Generator i germetizator shpura dlya hidroimpulsnogo vozdejstviya na ugolnyj massiv $\mathrm{v}$ tekhnologicheskom protsesse protivovybrosovykh meropriyatij. Geo-technical mechanics. Dnepropetrovsk, 61, 314-322

5. Vasyliev, L.M., Dzoz N.A., Zhulai Yu.A., Moyseenko P.Yu. (2009). Metodika opredeleniya parametrov kavitatsionnogo generator primenitelno $\mathrm{k}$ tekhnologii izvlecheniya metana iz ugolnykh plastov. Gornyj informatsionno-analiticheskij byulleten MGGU. Moskva: Mir gornoj knigi, 1, 157-160

6. Vasyliev, L.M., Zhulai Yu.A., Zberovskyi V.V. (2016). Razrabotka metoda rascheta parametrov ustrojstva gidroimpulsnogo vozdejstviya na vybrosoopasnye ugolnye plasty. Geotekhnicheskaya mekhanika. Dnepropetrovsk, 130, 92-169

7. Anhelovskyi, A.A. (2012). Opredelenie gidrodinamicheskih parametrov ustrojstva dlya impulsnogo ryhleniya ugolnyh plastov. Geo-technical mechanics. Dnepropetrovsk, 98, 114-119

8. Anhelovskyi, A.A. Zhulaj, Yu.A. (2012). Issledovanie dinamicheskih harakteristik kavitatsionnogo generatora i otsenka ih sootvetstviya parametram vybrosoopasnyh ugolnyh plastov. Zbirnyk naukovykh prats. NGU Ukraine, 37, 55-64

9. Anhelovskyi, A.A. Zhulaj, Yu.A., Zberovskyi V.V., Voroshylov, A.S. (2012). Issledovanie dinamicheskih harakteristik generatora uprugih kolebanij pri gidroryhlenii ugolnogo plasta. Zbirnyk naukovykh prats. NGU Ukraine, 38, 35-41

10. Dzenzerskyi, V.A., Zhulaj, Yu.A., Anhelovskyi, A.A. (2013) Opredelenie parametrov impulsnogo vozdejstviya pri gidroryhlenii vybrosoopasnyh ugolnyh plastov. Gornoe oborudovanie i elektromekhanika, 3, 43-48

11. Vasyliev, L.M., Potapenko, O.O., Anhelovskyi, O.A., Vasyliev, D.L., Usov, O.O., Trokhimets, M.Ya. (2012) Prystriy upravlinnya gidroimpulsnoyu dieyu na vugilniy plast. Patent No 68355, Ukraine

12. Pylypenko, V.V. (1989) Kavitatsionnye avtokolebaniya. Kyiv: Naukova dumka. 316

13. Vasyliev, L.M., Vasyliev, D.L., Zberovskij, V.V. (2014). Cavitation device of pulsed hydrolishing of coal seams. Geo-technical mechanics, 114, 162-169

14. Vasyliev, L.M., Vasyliev, D.L., Malich N.G. (2018). Mekhanika obrazovaniya form razrusheniya obraztsov gornykh porod pri ikh szhatii: monografiya. Dnipro: IMA-press 